\title{
Refinement of Miocene sea level and monsoon events from the sedimentary archive of the Maldives (Indian Ocean)
}

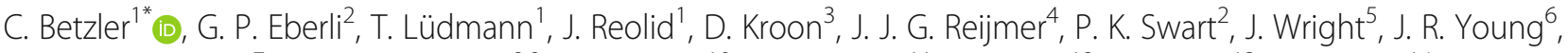 \\ C. Alvarez-Zarikian, M. Alonso-García, ${ }^{8,9}$, O. M. Bialik ${ }^{10}$, C. L. Blättler ${ }^{11}$, J. A. Guo ${ }^{12}$, S. Haffen ${ }^{13}$, S. Horozal ${ }^{14}$, \\ M. Inoue ${ }^{15}$, L. Jovane ${ }^{16}$, L. Lanci ${ }^{17}$, J. C. Laya ${ }^{18}$, A. L. Hui Mee' ${ }^{2}$, M. Nakakuni ${ }^{19}$, B. N. Nath ${ }^{20}$, K. Niino ${ }^{21}$, \\ L. M. Petruny ${ }^{22}$, S. D. Pratiwi ${ }^{23}$, A. L. Slagle ${ }^{24}$, C. R. Sloss ${ }^{25}$, X. Su ${ }^{26}$ and Z. Yao ${ }^{27,28}$
}

\begin{abstract}
International Ocean Discovery Program (IODP) Expedition 359 cored sediments from eight borehole locations in the carbonate platform of the Maldives in the Indian Ocean. The expedition set out to unravel the timing of Neogene climate changes, in particular the evolution of the South Asian monsoon and fluctuations of the sea level. The timing of these changes are assessed by dating resultant sedimentary alterations that mark stratigraphic turning points in the Neogene Maldives platform system. The first four turning points during the early and middle Miocene are related to sea-level changes. These are reliably recorded in the stratigraphy of the carbonate sequences in which sequence boundaries provide the ages of the sea-level lowstand. Phases of aggradational platform growth give precise age brackets of long-term sea-level high stands during the early Miocene and the early to middle Miocene Climate Optimum that is dated here between 17 to $15.1 \mathrm{Ma}$. The subsequent middle Miocene cooling coincident with the eastern Antarctic ice sheet expansion resulted in a long-term lowering of sea level that is reflected by a progradational platform growth. The change in platform architecture from aggradation to progradation marks this turning point at $15.1 \mathrm{Ma}$.

An abrupt change in sedimentation pattern is recognized across the entire archipelago at a sequence boundary dated as 12.9-13 Ma. At this turning point, the platform sedimentation switched to a current-controlled mode when the monsoon-wind-driven circulation started in the Indian Ocean. The similar age of the onset of drift deposition from monsoon-wind-driven circulation across the entire archipelago indicates an abrupt onset of monsoon winds in the Indian Ocean. Ten unconformities dissect the drift sequences, attesting changes in current strength or direction that are likely caused by the combined product of changes in the monsoon-wind intensity and sea level fluctuations in the last $13 \mathrm{Ma}$. A major shift in the drift packages is dated with $3.8 \mathrm{Ma}$ that coincides with the end of stepwise platform drowning and a reduction of the oxygen minimum zone in the Inner Sea.

The strata of the Maldives platform provides a detailed record of the extrinsic controlling factors on carbonate platform growth through time. This potential of carbonate platforms for dating the Neogene climate and current changes has been exploited in other platforms drilled by the Ocean Drilling Program. For example, Great Bahama Bank, the Queensland Plateau, and the platforms on the Marion Plateau show similar histories with sediment architectures driven by sea level in their early history (early to middle Miocene) replaced by current-driven drowning or partial drowning during their later history (Late Miocene). In all three platform systems, the influence of currents on sedimentations is reported between 11 and $13 \mathrm{Ma}$.
\end{abstract}

Keywords: Carbonate platform, Icehouse world, Sea level, Ocean circulation, Neogene, Indian Ocean

\footnotetext{
*Correspondence: christian.betzler@uni-hamburg.de

${ }^{1}$ Institute for Geology, CEN, University of Hamburg, Bundesstrasse 55, 20146

Hamburg, Germany

Full list of author information is available at the end of the article
} 


\section{Introduction}

The Neogene is a time of major changes in climate, sea level change, and ocean currents (Flower and Kennett 1994, Zachos et al. 2001). In regard to climate, the middle Miocene experienced a warm period known as the Miocene Climate Optimum (MCO) which was followed by a general cooling that culminated in the onset of northern hemisphere glaciation at about $2.8 \mathrm{Ma}$. Sea level reaches a high during the $\mathrm{MCO}$ with subsequent lower sea level and higher amplitudes of sea level fluctuations (Miller et al. 2005, 2011). The modern global circulation system established in the Miocene and is still active today (Poore et al. 2006; Wright and Miller 1996). The South Asian Monsoon (SAM), one of the most intense modern climatic elements, developed during the Miocene (Betzler et al. 2016a). An increase of sediment flux into the Indian Ocean occurred around $11 \mathrm{Ma}$ (Rea 1992; Zheng et al. 2004), and a peak in the sedimentation rates of the Indus Fan took place between 16 and $10 \mathrm{Ma}$ (Clift et al. 2008). In addition, the onset of monsoonal-triggered marine upwelling at $\sim 8.5 \mathrm{Ma}$ indicates a strengthening of the monsoon system at this time (Kroon et al. 1991). The Maldives archipelago contains the sedimentary record of all these paleo sea-level, climatic, and oceanographic changes. The biostratigraphically dated cores drilled at various locations of the platform-basin system offer the opportunity to date these changes with high precision.

The Miocene sea-level changes are recorded in the architecture of carbonate platforms of the archipelago that has been imaged in a variety of seismic data sets (Purdy and Bertram 1993; Aubert and Droxler 1996; Belopolsky and Droxler 2004a, 2004b; Betzler et al. 2009, 2013a; Lüdmann et al. 2013). The response to the middle MCO and its high sea level, for example, is documented by aggrading carbonate platform growth, while the subsequent cooling and lowering of sea level results in platform progradation and no aggradation (Betzler et al. 2009). The modern SAM is an atmospheric circulation pattern with reversing winds during the winter and the summer monsoon. This atmospheric circulation produces an annual reversing current system in the Indian Ocean (Tomczak and Godfrey 2003). These currents transport sediments into the Inner Sea of the Maldives and deposited in thick drift deposits. These drifts in the Inner Sea are a formidable record of the onset and variations of the monsoon winds (Betzler et al. 2016a).

The timing of paleoclimatic and paleoceanographic changes can be recorded geochemically, such as in the $\delta^{18} \mathrm{O}$ values of benthic foraminifer tests, and also physically, in the sediments themselves. A common approach to assess timing of temperature and size of Earth's cryosphere is constructing stacks and compilations of $\delta^{18} \mathrm{O}_{\text {benthic }}$ values (Lisiecki and Raymo 2005; Cramer et al. 2009; Zachos et al. 2001, De Vleeschouwer et al. 2017). The stable oxygen isotope records are powerful proxies to monitor trends but also to record highfrequency changes caused by orbital forcing (Lisiecki and Raymo 2005; Bell et al. 2015; De Vleeschouwer et al. 2017). However, this proxy record may be less accurate in defining the exact time when an environment is pushed over a threshold that could produce lasting changes in the climate system. For example, it is difficult to pinpoint on the oxygen isotope curve the answers to questions such as: when in the Middle MCO did rates of sea level change increase so drastically that coral systems had to adjust, or when did the strengthening of the monsoon winds trigger changes in the oceanic circulation pattern. In contrast, in the sedimentary record, high-frequency changes driven by orbital forcing are muted, but major turning points and thresholds are expressed precisely because deposition is generally driven by one dominating factor that overrides other variables.

The Maldives archipelago contains the sedimentary record of Neogene climate changes in the carbonate sediments of the atolls and the deep Inner Sea. The Maldives carbonate edifice is a carbonate platform with a twofold configuration of atoll growth and deposition of contourites and drifts in areas just some kilometers apart (Betzler et al. 2009, 2013a, 2013b; Lüdmann et al. 2013). Sea-level changes and ocean current interacted during the evolution of the carbonate platforms, and one or the other factor determined the major changeovers in the platform evolution. Unconformities mark these points, and these unconformities can be recognized on seismic data throughout the archipelago. Cores retrieved during IODP Expedition 359 enable us to date these unconformities and provide the exact timing within the resolution of biostratigraphy of these major turning points. Previous works established that the currents established abruptly, in response to the onset of the Indian Monsoon around 12.9 Ma (Betzler et al. 2016a). This paper describes the correlation of the seismic data with the sediment cores and their lithology and discusses the turning points in these seismic and sedimentary records in the light of the global changes during the Neogene. Furthermore, the sedimentary architecture of the Maldives and timing of changes therein can be compared to other carbonate platforms in the Caribbean and the Coral Sea within the context of global climate change.

\section{Geological and oceanographic setting of the Maldives}

Modern morphology and oceanographic setting

The chain of the Maldives archipelago in the central equatorial Indian Ocean is an isolated tropical carbonate platform edifice constituting the central and largest part 
of the Chagos-Laccadive Ridge, located southwest of India (Fig. 1a). A north- to south-oriented double row of atolls encloses up to $550 \mathrm{~m}$ deep Inner Sea of the Maldives (Fig. 1b). Inter-atoll channels that deepen towards the Indian Ocean separate the atolls (Fig. 1b, c). The modern archipelago comprises about 1200 smaller atolls that lie near or slightly above the sea surface. The oceanward margins of the Maldives archipelago are generally steeply inclined, with dips of $20^{\circ}-30^{\circ}$ to $2000 \mathrm{~m}$ water depth. On the Inner Sea side, terraced atoll slopes have the same dip angles but reach water depths of only $150 \mathrm{~m}$, where the gradient rapidly declines (Betzler et al. 2016a; Fürstenau et al. 2010). Sediment-drift bodies surround the atolls in the Inner Sea (Betzler et al. 2009, 2013a, 2013b, 2016a, 2016b; Lüdmann et al. 2013). The seasonally reversing Indian monsoon system influences the oceanographic and depositional processes (Tomczak and Godfrey 2003). Southwestern winds prevail during
Northern Hemisphere summer (April-November) while northeastern winds prevail during winter (DecemberMarch). These winds generate ocean currents that are directed westward in the winter and eastward in the summer. Inter-seasonally, a band of Indian Ocean equatorial westerlies are established, enforcing strong eastward-flowing surface currents with velocities up to $1.3 \mathrm{~m} / \mathrm{s}$. Currents reach water depths of more than $200 \mathrm{~m}$ with only slightly reduced velocities (Tomczak and Godfrey 2003). Within the modern atolls' passages, currents can reach velocities of up to $2 \mathrm{~m} / \mathrm{s}$.

\section{Evolution of the Maldives}

The Maldives archipelago comprises an approximately $3 \mathrm{~km}$ thick shallow water and hemipelagic carbonate succession (Aubert and Droxler 1992; Purdy and Betram 1993) (Fig. 1d) that formed on a lower Paleogene (60$50 \mathrm{Ma}$ ) volcanic basement (Duncan and Hargraves 1990).

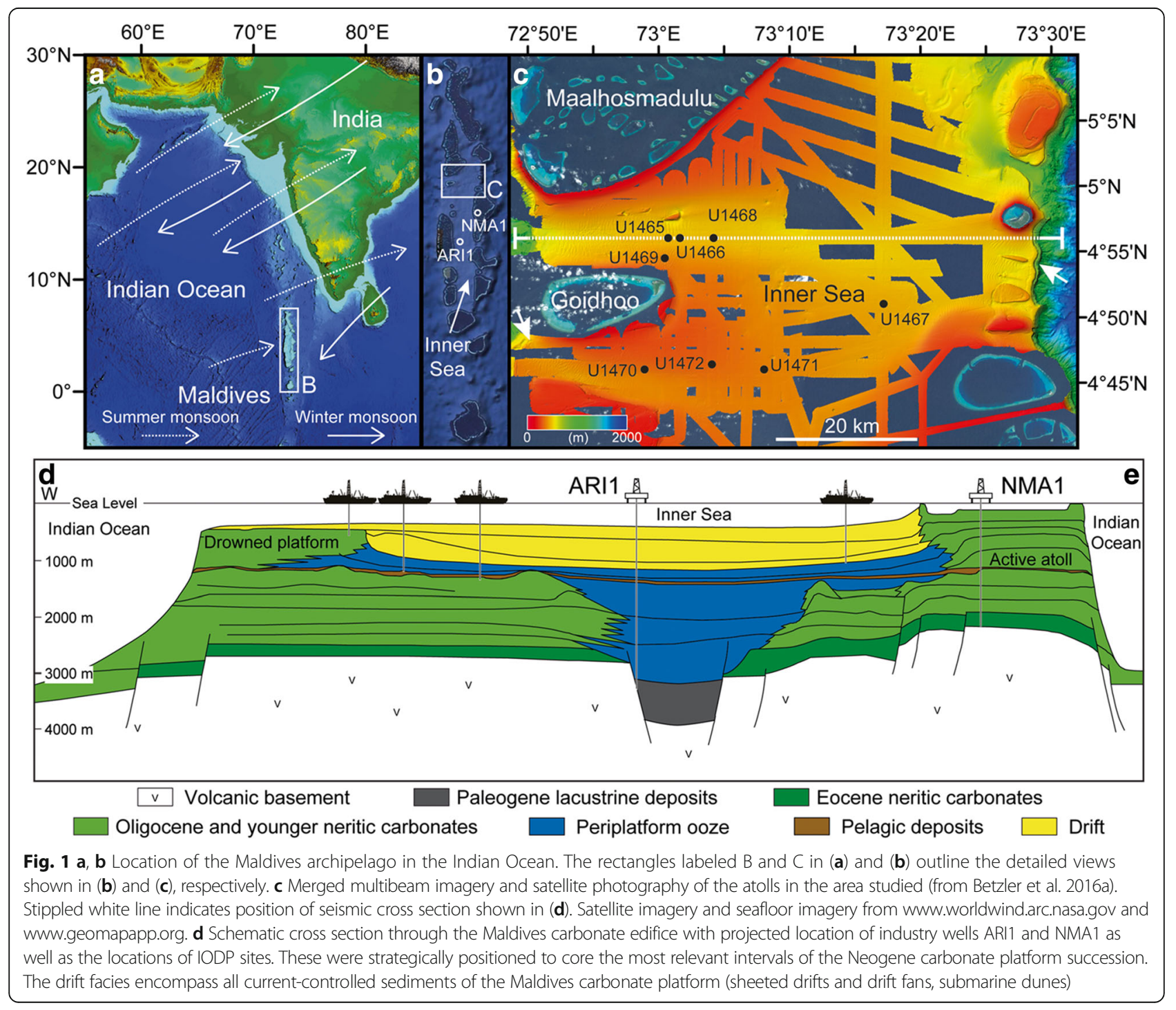


During the early Eocene, carbonate production was established, when flat-topped carbonate banks originated on topographic highs created by the volcanic basement. During the late Oligocene, bank margins typically had elevated rims that separated bank-interior areas from the open ocean. During the early Miocene, carbonate production became restricted to narrow bands at the respective most oceanward areas, forming the double row of platforms. During the Miocene, platform margins prograded towards the Inner Sea, as recognized in different versions of seismic reflection data, irrespective of seismic resolution (Purdy and Bertram 1993; Aubert and Droxler 1996; Belopolsky and Droxler 2004a, 2004b; Betzler et al. 2009, 2013a; Lüdmann et al. 2013).

Coincident with the partial drowning of the Maldives carbonate bank, drift deposits occupied the Inner Sea and the flanks of the atolls (Betzler et al. 2009, 2013a, 2013b, 2016a, 2016b, Lüdmann et al. 2013). The current control on the platform evolution continues until today and can be linked to the Indian Monsoon circulation (Betzler et al. 2016a). Since the inception of the currents, two additional drowning steps have affected the Maldives (Betzler et al. 2009, 2013a). Flat-topped and atoll-shaped banks are interpreted to have drowned quickly, whereas mound-shaped banks are interpreted to have undergone sequential drowning under elevated nutrient fluxes (Betzler et al. 2009), similar to banks described by Zampetti et al. (2004) offshore Malaysia.

\section{Methods/Experimental}

The data consist of two main packages: (1) a set of seismic data from various vintages (Betzler et al. 2013a, 2013b, Lüdmann et al. 2013) and (2) the coring and logging data collected during IODP Expedition 359 (Betzler et al. 2017). The vertical resolution of the seismic data is approximately 4-6 m, depending on depth. In addition, published low- to medium-resolution industrial reflection seismic lines shot for Elf in 1973-1974 (Purdy and Bertram 1993; Aubert and Droxler 1996) and for Shell in 1989-1990 (Belopolsky and Droxler 2004a, 2004b) were used for regional context and initial sequence analysis. Interpretation and visualization was performed on time-migrated data in the time domain using the software package Petrel (Schlumberger). All seismic data were tied to the seafloor topography computed from the multibeam data acquired during the site survey.

During Expedition 359, eight sites were drilled along two transects in the Kardiva Channel in the Inner Sea of the Maldives (Figs. 1, 2, 3, 4, and 5). Core retrieval, handling and all on board measurements including downhole logging are described in detail in the methods section of the Expedition 359 Proceedings Volume (Betzler et al. 2017).

The age assignments of the successions drilled rely on calcareous nannoplankton and planktonic foraminiferal events (Table 1). For the calcareous nannoplankton, the standard zonal scheme of Martini (1971) was adopted as a general frame of reference. However, for age models and inter-site calibration, individual events were used according to their reliability and ease of recognition irrespective of whether they formed part of the standard zonation. The compilations of Backman et al. (2012) and Raffi et al. (2006) were used to provide additional information on the reliability, definition, and timing of events. For the planktic foraminifers, see Betzler et al. (2017).

The core to seismic correlation relies on an accurate $\mathrm{P}$ wave velocity model for time-depth conversion. Two checkshot surveys were performed at dedicated logging holes (U1467E and U1471E). At Site U1467, the

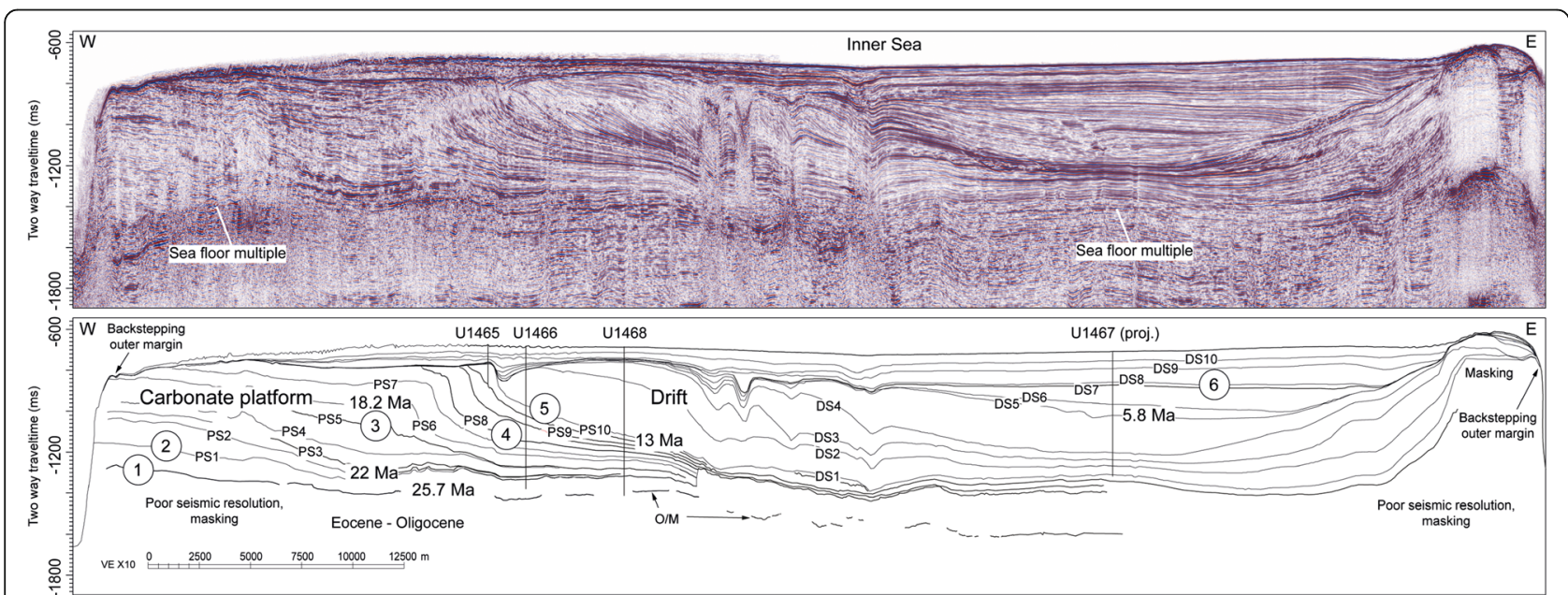

Fig. 2 Seismic line across the Maldives Inner Sea (for location of line see Fig. 1c) with line drawing showing the platform sequence boundaries (PS) and the drift sequence boundaries (DS). Ages of selected horizons are given. For a complete overview of sequence boundary ages see Table 2. Numbers 1-6 refer to the turning points of the platform evolution discussed in the text 


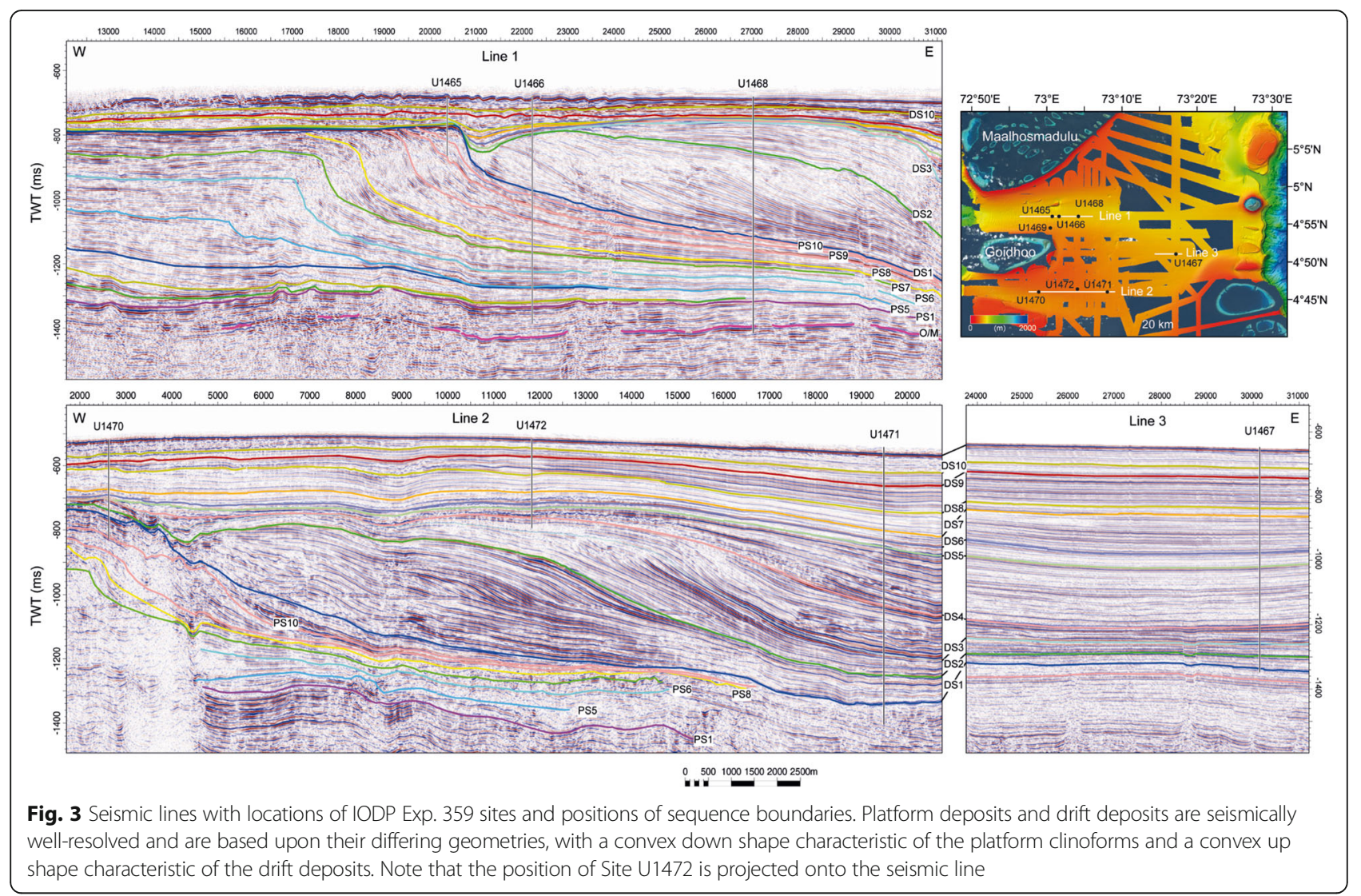

waveforms of the recorded shots were of high quality with a high signal-to-noise ratio, and consequently, first arrival times were easy to pick (Fig. 5). The velocity in the oldest drift sequences (DS1-DS3) reaches 2600$3000 \mathrm{~m} / \mathrm{s}$. At sites where logging operations could not be fully conducted, the time-depth conversion relies on fixed points provided by the cored formation, such as for example the contact between the indurated Oligocene shallow water limestone and the overlying chalky deposits (Oligocene/Miocene sequence boundary).

\section{Results and interpretation \\ Seismic stratigraphy}

The seismic and core data set covers the inner part of the Maldivian archipelago (Fig. 1). Two transects of sites aligned along two 2D seismic lines in this area cover the Neogene succession of the Inner Sea of the Maldives (Fig. 3). Here, previous work identified a drowned carbonate bank with drift deposits adjacent and overlying the drowned platform (Aubert and Droxler 1996, Belopolsky and Droxler 2004a, 2004b; Betzler et al. 2009, 2013a; Lüdmann et al. 2013).

Prior to the drilling of eight sites in the Inner Sea of the Maldives during Expedition 359, a preliminary sequence analysis had been performed on the seismic data
(Betzler et al. 2013a, 2013b; Lüdmann et al. 2013) (Fig. 3), amending previous work of Belopolsky and Droxler (2004a, 2004b). Erosional truncations and onlap geometries were applied to define sequence boundaries, and 22 sequences were differentiated. Lower-bounding sequence boundaries and overlying correlative seismic sequences were labeled as platform sequence boundaries 1 to 11 (PS1-PS11) and platform sequence 1 to 11 (ps1-ps11) in the drowned Neogene carbonate bank, and as drift sequence boundary 1 to 10 (DS1-DS10) and drift sequences 1 to 10 (ds1-ds10) in the drift deposits (Figs. 2, 3) from older to younger age, respectively. The ages of these sequence boundaries are here examined and refined using the shipboard biostratigraphy.

Several of these sequence boundaries delimit stratigraphic packages with distinct growth characteristics. These boundaries are marked as "turning points" in Fig. 2. The lowermost boundary, horizon $\mathrm{O} / \mathrm{M}$, is traceable as a distinct seismic reflection throughout the data coverage and was placed into the Late Oligocene in previous works (Aubert and Droxler 1996; Belopolsky and Droxler 2004a, 2004b). This horizon has been identified as a drowning unconformity terminating the growth of carbonate banks several 10s of kilometers in width, and is the first turning point in the investigated strata. 


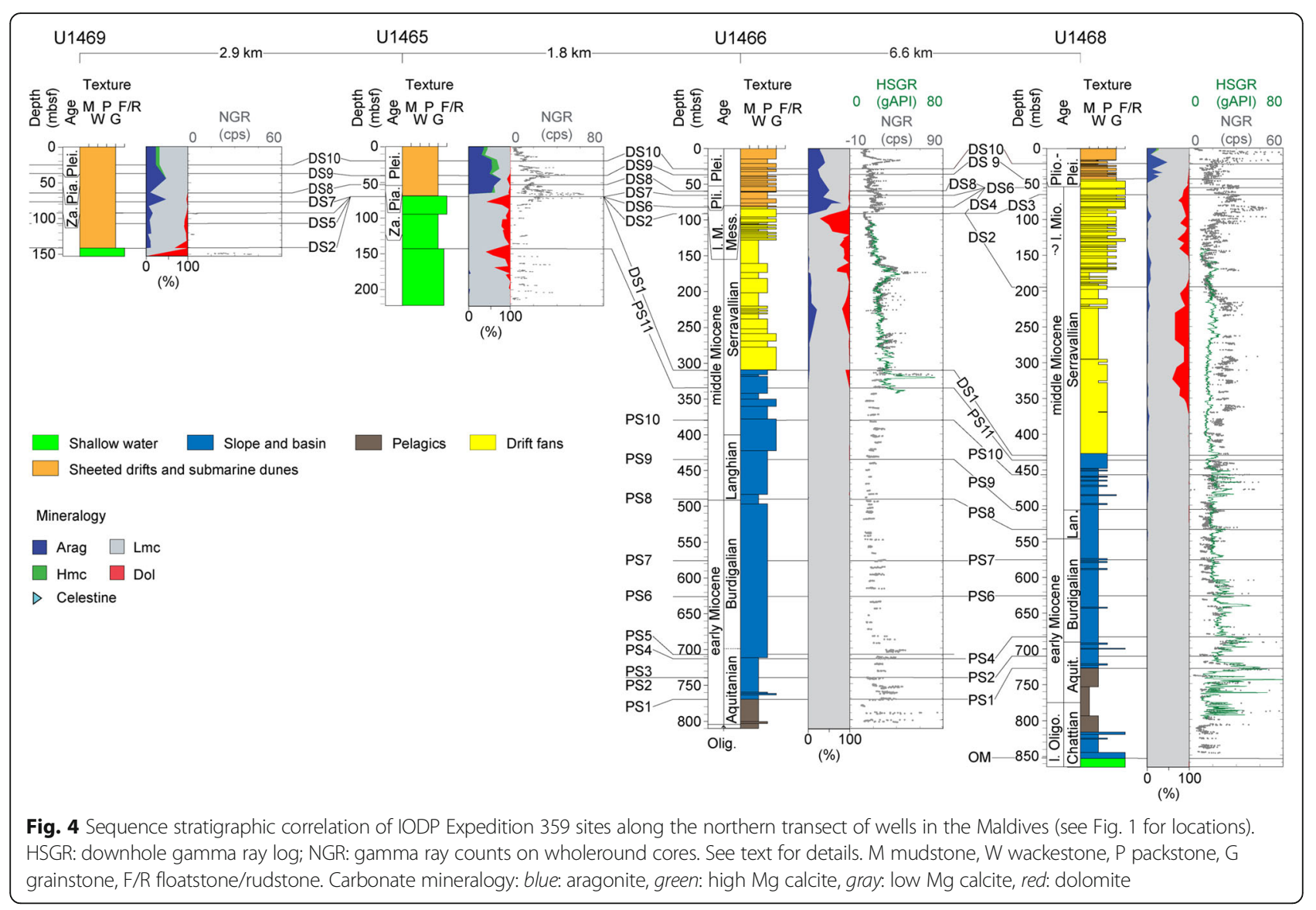

Shallow water sedimentation eventually resumed on the drowned edifice during the latest Oligocene and Early Miocene. The banks with widths of ca. $5 \mathrm{~km}$ were therefore much narrower than the Oligocene precursor edifices and were characterized by a low relief from the bank top to the basin (Figs. 1 and 2). Furthermore, no reefs can be differentiated in seismic data (Aubert and Droxler 1996). Subsequently, a shallow-water succession developed in which 11 seismic sequences are recognized (Betzler et al. 2013a; Fig. 2). The sequence boundary PS1 is the second turning point and corresponds to the base of a stratigraphic package with a ramp depositional profile, which steepens through time in sequences ps 2, 3, and 4, until a platform with a steep rim forms sequence ps4 (Fig. 2). Ramp sequences ps 2 and 3 aggrade, and sequence ps4 progrades on the eastern rim of carbonate platform and thereby widened it eastward to around 7$8 \mathrm{~km}$ (Fig. 2). The same pattern is recognized elsewhere in the Maldives edifice where the seaward progradation is less in the carbonate banks located on the eastern part of the Inner Sea when compared to the western carbonate banks (Aubert and Droxler 1992, 1996).

Progradation is halted in sequence ps 5 and changes to a pronounced aggradation in seismic sequences ps6 and ps7. Sequence boundary PS5 marks this transition and is defined as third turning point (Fig. 2). At the same time, a backstepping of the outer platform margins facing the open Indian Ocean occurred (Betzler et al. 2009, 2013a). Aggradation changes back into progradation at SB PS8, which is the fourth turning point. Progradation continues in the next three sequences but terminates with sequence ps 11 . The end of the progradation marks the most pronounced turning point 5 in the sedimentation pattern, which corresponds to sequence boundary DS1.

At this turning point in the upper middle Miocene (Fig. 2), large-scale lobate clinoform bodies are deposited by currents in the Inner Sea representing the onset of current-controlled deposition (Betzler et al. 2013a; Lüdmann et al. 2013). The currents themselves are driven by the monsoon winds that start at 12.9-13 Ma (Betzler et al. 2016a). These drift bodies are funneled through passages where some platforms had drowned, while remaining banks and atolls continued to grow (Betzler et al. 2009, 2013a). These atolls are characterized by aggrading margins (Betzler et al. 2009, 2016b) with the exception of the current-protected flanks facing towards the Inner Sea, where some margins show progradation (Belopolsky and Droxler 2004a, 2004b, Betzler et al. 2013a, 2013b). Lobes are fed by easterly currents and reworked by a current system flowing 


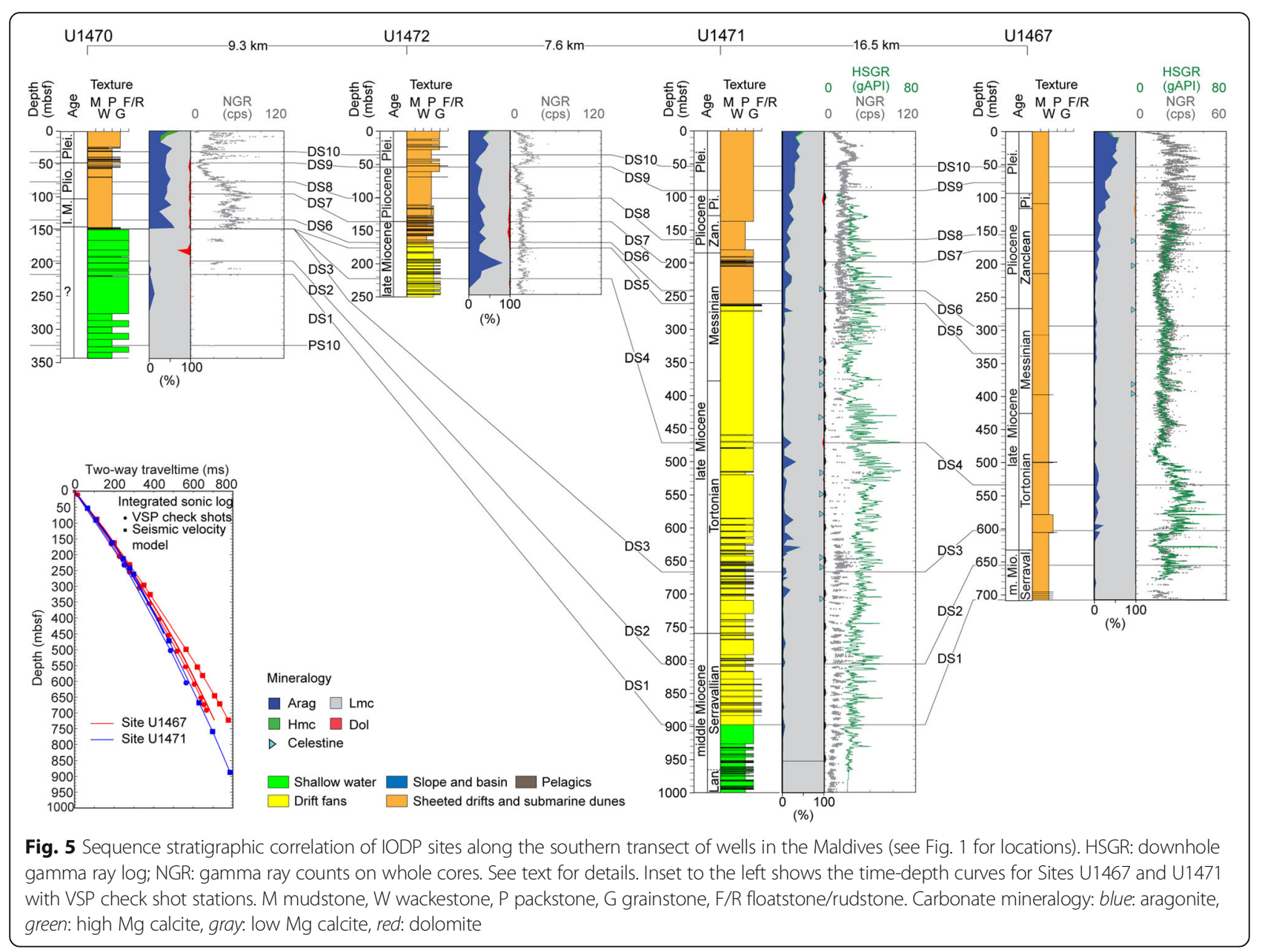

obliquely or normally to this main stream (Betzler et al. 2013a). This current pattern filled the Inner Sea from west to east (Lüdmann et al. 2013). Starting with seismic sequence ds6, the opening of a southern gateway introduced northward flow of bottom water into the Inner Sea, leading to deposition of giant elongated drifts at the eastern flank of the basin, filling it from east to west (Lüdmann et al. 2013).

The last turning point in the platform evolution, turning point 6 at DS8, is the end of an episode which was characterized by several steps of partial carbonate platform drowning. This process is documented in the studies done by Betzler et al. (2009, 2013a) and Lüdmann et al. (2013).

\section{The sedimentary record}

In the following paragraph, the facies of five different environments that were recovered in the cores are described. They consist of (1) shallow-water carbonate platform, (2) carbonate platform slope, and (3) basin, (4) pelagic chalk, and (5) carbonate drift. With an overall core recovery rate of $57 \%$, a reasonable core to seismic correlation can be performed and the seismic sequence boundaries can be positioned in the cores (Figs. 4 and 5, Table 2).

\section{Shallow-water platform facies}

Shallow-water carbonate platform facies were recovered from the upper Oligocene (Site U1468) and the middle Miocene (Sites U1465, U1469, and U1470) (Figs. 4 and 5). Shallow water deposits consist of packstone to rudstone with red algae, large benthic foraminifers, and corals (Fig. 6a).

\section{Outer platform and platform slope facies}

Distal carbonate platform slope deposits make up more than $500 \mathrm{~m}$ at Site U1466 and more than $250 \mathrm{~m}$ at Site U1468. Slopes pertain to the Miocene carbonate platform and form clinoform geometries. Outer platform and slope deposits consist of an alternation of decametric thick intervals of lithified fine- to medium-grained packstone and wackestone with discrete chert layers. Contacts between distinct intervals are gradational and consist of changes in bioturbation intensity and sediment color from grayish brown to light brownish gray 
Betzler et al. Progress in Earth and Planetary Science (2018) 5:5

Page 8 of 18

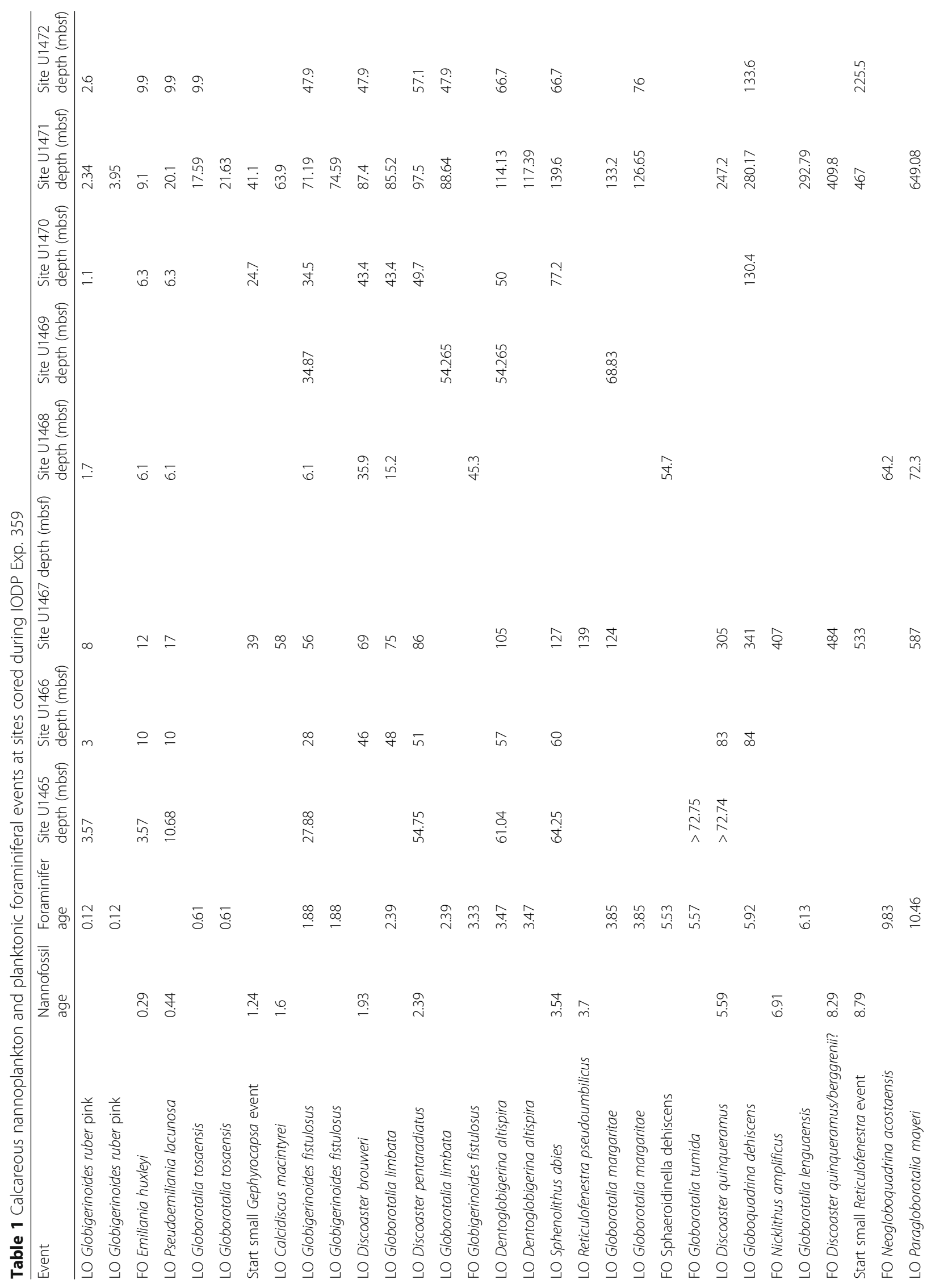




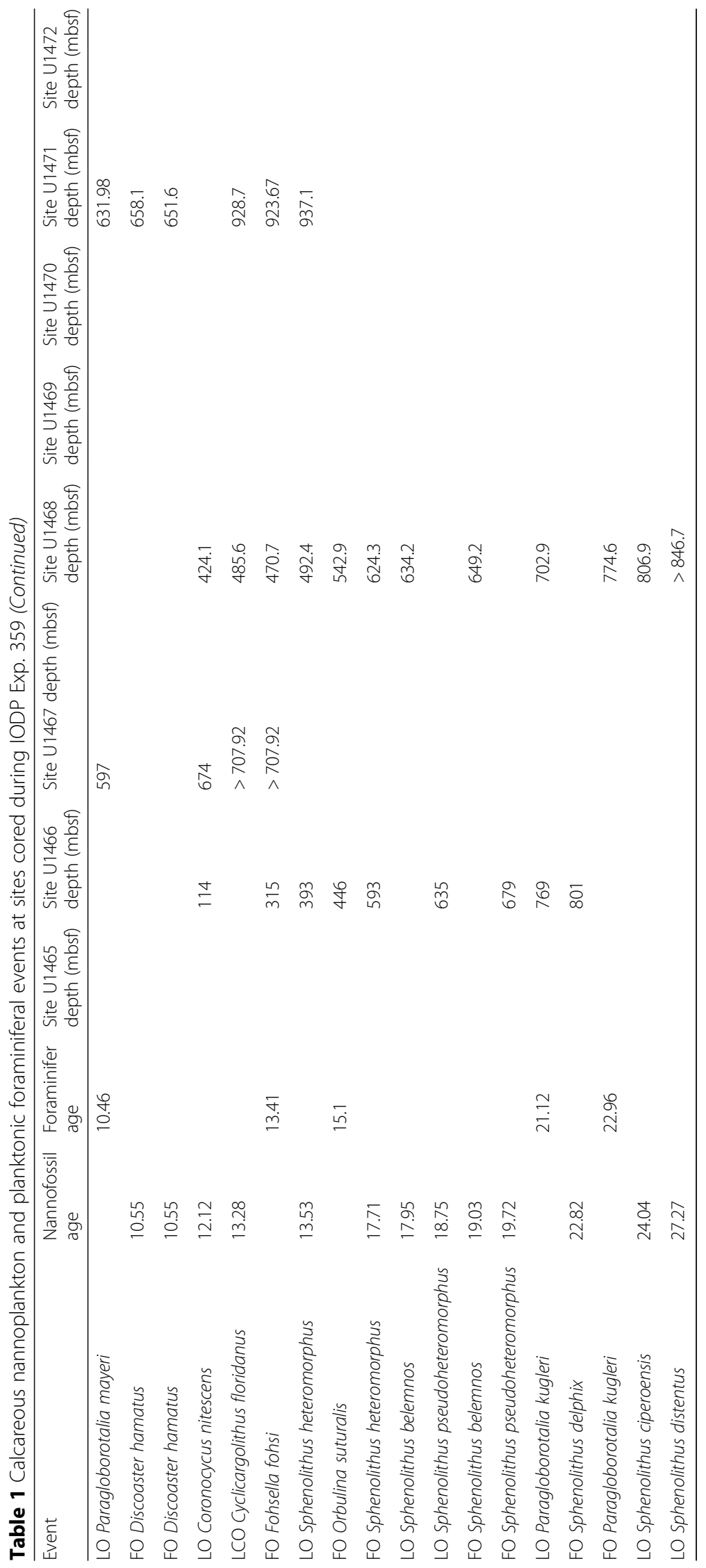


Table 2 Depths and ages of sequence boundaries at sites cored during IODP Exp. 359. Positions of these horizons are shown in Figs. 4 and 5

\begin{tabular}{|c|c|c|c|c|c|c|c|c|c|c|c|c|c|c|c|c|}
\hline & \multicolumn{2}{|c|}{ Site U1465 } & \multicolumn{2}{|c|}{ Site U1466 } & \multicolumn{2}{|c|}{ Site U1467 } & \multicolumn{2}{|c|}{ Site U1468 } & \multicolumn{2}{|c|}{ Site U1469 } & \multicolumn{2}{|c|}{ Site U1470 } & \multicolumn{2}{|c|}{ Site U1471 } & \multicolumn{2}{|c|}{ Site U1472 } \\
\hline & (Ma) & $(m b s f)$ & $(\mathrm{Ma})$ & $(\mathrm{mbsf})$ & $(\mathrm{Ma})$ & (mbsf) & $(\mathrm{Ma})$ & (mbsf) & $(\mathrm{Ma})$ & (mbsf) & (Ma) & (mbsf) & $(\mathrm{Ma})$ & (mbsf) & (Ma) & (mbsf) \\
\hline DS10 & 1.45 & 29 & 1.50 & 28 & 1.50 & 52.5 & & 22.5 & & 25 & 1.55 & 31 & 1.40 & 53 & 1.35 & 33.5 \\
\hline DS9 & 2.15 & 40.5 & 2.00 & 38 & 2.10 & 78 & & 43 & & 38 & 2.30 & 49 & 2.10 & 90 & 2.15 & 54 \\
\hline DS8 & 2.85 & 52.5 & 3.60 & 60 & 3.90 & 157.5 & & & & 64.5 & 3.65 & 78 & 4.00 & 166 & 4.00 & 100 \\
\hline DS7 & & 70 & 4.10 & 65 & 4.20 & 181.5 & & & & 77.5 & 4.35 & 93 & 4.60 & 198 & 5.30 & 135 \\
\hline DS6 & & & 5.60 & 81 & 5.50 & 295.5 & & & & 93 & & 135 & 5.50 & 242.5 & 6.60 & 168 \\
\hline DS5 & & & & & 5.80 & 337 & & & & 107.5 & & & 5.80 & 261.5 & 6.90 & 176 \\
\hline DS4 & & & & & 8.80 & 535 & & 55 & & & & & 8.80 & 471.5 & 8.80 & 223 \\
\hline DS3 & & & & & 10.50 & 603 & & 65 & & & & 148.5 & 10.60 & 667 & & \\
\hline DS2 & & & & 94 & 11.70 & 656.5 & 11.30 & 191 & & & & 198 & 12.00 & 804.5 & & \\
\hline DS1 & & & 12.70 & 310 & 13.00 & 711 & 13.00 & 430 & & 141.5 & & 217 & 12.90 & 898 & & \\
\hline PS11 & & 142 & 12.85 & 336 & & & 13.10 & 438 & & & & 324.5 & & & & \\
\hline PS10 & & & 13.10 & 380 & & & 13.20 & 457 & & & & & & & & \\
\hline PS09 & & & 14.2 & 435 & & & 14.2 & 505 & & & & & & & & \\
\hline PS08 & & & 15.1 & 490 & & & 15.1 & 535 & & & & & & & & \\
\hline PS07 & & & 15.60 & 525 & & & 16.10 & 573 & & & & & & & & \\
\hline PS06 & & & 17.00 & 625 & & & 17.50 & 626 & & & & & & & & \\
\hline PS05 & & & 18.50 & 709 & & & & 662 & & & & & & & & \\
\hline PSO4 & & & 18.60 & 712 & & & & 682 & & & & & & & & \\
\hline \multicolumn{17}{|l|}{ PSO3 } \\
\hline PSO2 & & & & & & & 21.30 & 710 & & & & & & & & \\
\hline PS01 & & & 20.10 & 770 & & & 21.80 & 730 & & & & & & & & \\
\hline $\mathrm{O} / \mathrm{M}$ & & & & & & & 25.65 & 854.7 & & & & & & & & \\
\hline
\end{tabular}

(Figs. 6b, c). Planktonic and benthic foraminifers, echinoid fragments, and other bioclasts are common, and the matrix contains calcareous nannofossils and aragonite needles. Darker intervals contain organic matter and no clays. The NGR (gamma ray counts on wholeround cores) intensity of the sediment varies with the organic content, and organic-rich intervals have a higher gamma radiation compared to organic-poor sedimentary intervals.

Bioturbation is pervasive, resulting in a completely mottled appearance. At Site U1468, two convoluted intervals were recovered in the cores at 641.3 and 700.2 mbsf. Other soft-sediment deformation features and graded layers with sharp bases occur at Site U1466 at a depth of 731.4 mbsf (Fig. 6b). Deposits rich in large benthic foraminifers (Operculina sp., Lepidocyclina [Eulepidina] sp., Heterostegina sp., and Nummulites sp.) occur at $760 \mathrm{mbsf}$ and are overlain by convoluted layers and a very coarse grained to gravel rudstone (50R-1, 17-19 cm). The rudstone contains abundant large benthic and planktonic foraminifers, Halimeda, red algae, fragmented gastropods, and bivalves. Common (at least two species present) coral fragments up to $1 \mathrm{~cm}$ in size were identified.
The outer platform zone of the Oligocene platform was recovered at Site U1468. Deposits are wackestones to floatstone with large benthic foraminifers and planktonic foraminifers.

\section{Basinal and pelagic facies}

A pelagic facies in the lower part of the sedimentary successions at Site U1466 and U1468 includes black, organic-rich (up to $8 \%$ TOC) planktonic foraminifer, and nannofossil chalks (mudstone-wackestone) with a faint lamination (Fig. 6d). These organic-rich sediments occur as dark $1-25 \mathrm{~cm}$ thick intervals which are intercalated with white calcareous nannoplankton and planktonic foraminifer chalks (mudstones-wackestones) with some bioturbation.

\section{Submarine dunes and drift facies}

Submarine dunes were penetrated in the upper part of the sedimentary succession at Sites U1465, U1466, U1468, U1469, and U1470 (Figs. 4 and 5). Deposits have a packstone to grainstone texture and contain abundant planktonic and benthic foraminifers together with 

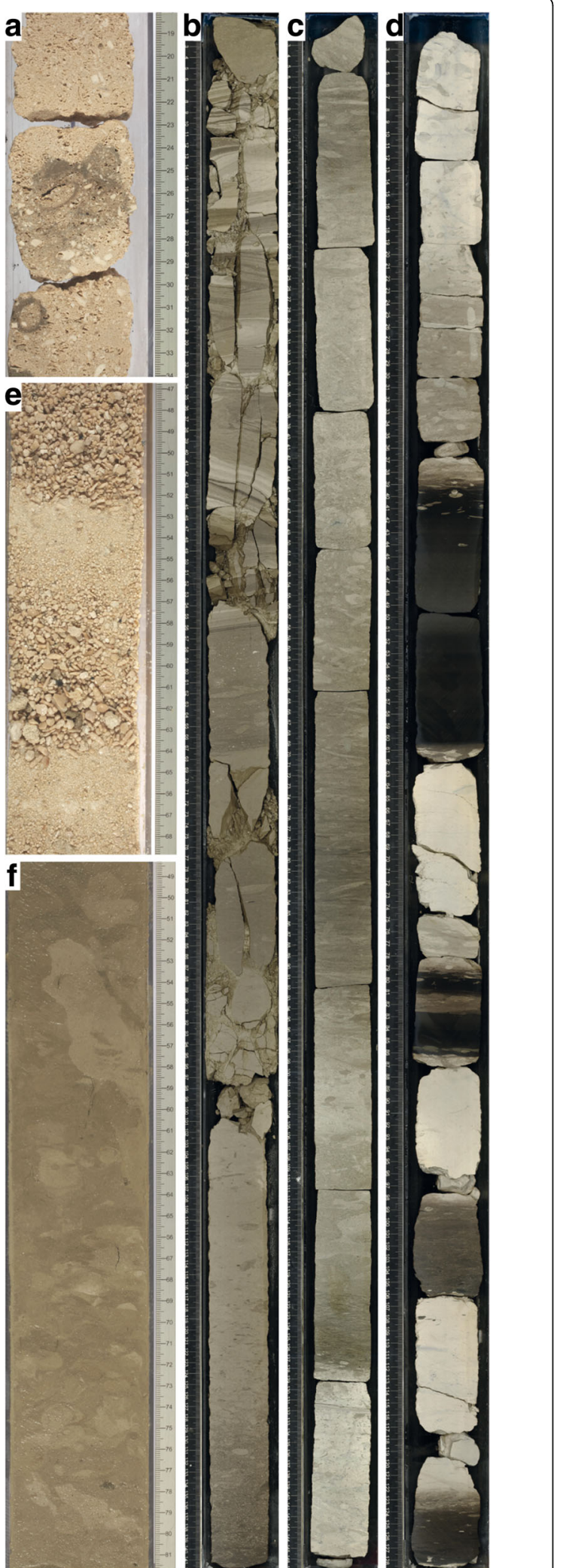

Fig. 6 Core photographs of the drift and carbonate platform facies discussed in the text. a Shallow water limestone with red algal debris and bioclasts (Core 359-U1465B-4R-1, 18-34 cm). b Slope deposits with slumped layers (Core 359-U1466B-52R-3, 0-150 cm). c Distal slope to basin deposits characterized by intervals with higher platform export (lighter color) and intervals with reduced platform export (darker color) (Core 359-U1471E-43R-1. 0-150 cm). d Pelagic chalks with dark TOCrich intervals (Core U1466B-56R-1, 0-150 cm). e Drift fan deposits with an alternation of coarser and finer grained bioclastic sands (Core U1468A-17F-1, 46.5-68.9 cm). f Sheeted drifts deposited in areas of a quiet hydrodynamic regime (Core U1467B-44H-4A, 48.3-81.7 cm)

lithoclasts and shallow water components such as Halimeda flakes (Fig. 6e).

Drift fan deposits were recovered at Sites U1466, U1468, U1471, and U1472 (Figs. 4 and 5). Sediments show a textural variation from wackestone to rudstone. At Sites U1466 and U1468, the drift fan successions show a fining-upward trend in the lower part of the depositional package followed by a coarsening-upward trend in its upper part. Wackestones and packstones within the drift fan are bioclastic with benthic and planktonic foraminifers. The main components of the grainstones and rudstones are large benthic foraminifers (Amphistegina, Lepidocyclina, Miogypsinoides, Heterostegina, Operculina, and Sphaerogypsina) together with echinoid spines, red algae, mollusk fragments, bryozoans, Halimeda plates, and aggregate grains.

Sheeted and plastered drift deposits range from wackestones to grainstones at Sites U1467, U1470, U1471, and U1472 (Fig. 3). Coarser sediments were recovered at the western end of Kardiva Channel, while at Site U1467, i.e., in a more current-protected area, the succession are dominated by wackestone. Sheeted drift sediments are bioturbated throughout and contain abundant planktonic and benthic foraminifers together with bioclasts (Fig. 6f).

\section{The gamma ray log record of the major sedimentary changes}

Downhole, gamma ray logs in general show low values with maxima around 80 gAPI (Figs. 4 and 5). Variations in gamma ray log are controlled by the uranium content of the sediments and, therefore, trace variations of organic content (Betzler et al. 2017). At Site U1468, the gamma ray $\log$ is subdivided into two intervals. The boundary between these intervals correlates with the base of the drift sequences, i.e., DS1 (Fig. 4).

The lower interval shows high log values either in the organic-rich deposits of the restricted basin facies or at around sequence boundaries (Fig. 4). Above DS1, the gamma ray log values in general show a lower variability than the values of the platform sequences. The drift deposits, which were logged at Sites U1466, U1467, and U1471 (Figs. 4 and 5), display variable log signatures that 
do not to follow sequence stratigraphic surfaces or show any change at these surfaces.

\section{Age model}

The sedimentary successions contain variable amounts of age diagnostic microfossils and in some intervals diagenesis obliterate diagnostic characteristics. The dense set of cores along the two transects, however, provide a robust biostratigraphic framework for age determination by planktonic foraminifers and nannofossils (Table 1). Here, an overview is given of the best sites and the challenges in others.

The most useful sequence of biostratigraphic events is found in the cores from Sites U1471 and U1472 (Betzler et al. 2017). They allow a clear age model.

At Site U1466, most of the late Miocene interval is absent from the sedimentary record, and a hiatus is inferred between 12.12 and $5.92 \mathrm{Ma}$. However, the succession recovered at Site U1467 is characterized by well-constrained events (Table 1). In addition, magnetostratigraphy shows reliable results from $\sim 100$ to 200 mbsf. Data commence with a long reversed interval that, when compared to the biostratigraphic data, was confidently identified as the Gauss magnetochron, C2Ar. Following from this, a succession of subchrons was identified within Chron C3n. In the lower part of the section, assemblages of both nannofossils and planktonic foraminifers are sufficiently well preserved to state with confidence that the base of the section is younger than 13.3-13.4 Ma.

At Site U1468, the age model for the upper part of the succession is poorly constrained because most nannofossil zonal markers are missing (Table 1). Below a hiatus of $\sim 8$ My (Fig. 7), both the nannofossils and planktonic foraminifers are very poorly preserved and/or diluted throughout, hampering assignment of zonal boundaries and/or reliable datum levels. Preservation and abundance of planktonic microfossils increase abruptly below $\sim 440$ mbsf, which coincides with the base of the drift deposits. In the lower part of the succession, preservation and abundance of planktonic calcareous microfossils are variable, but many samples yielded welldeveloped assemblages. Therefore, several reliable events were placed. By extrapolating the linear trend of the average sedimentation rate to the base of the interval, an age of $\sim 26 \mathrm{Ma}$ was estimated for the bottom of the interval.

At Sites U1465 and U1469, the shallow water limestone below sequence boundary DS1 contains large benthic foraminifera of the genus Miogypsinoides, which

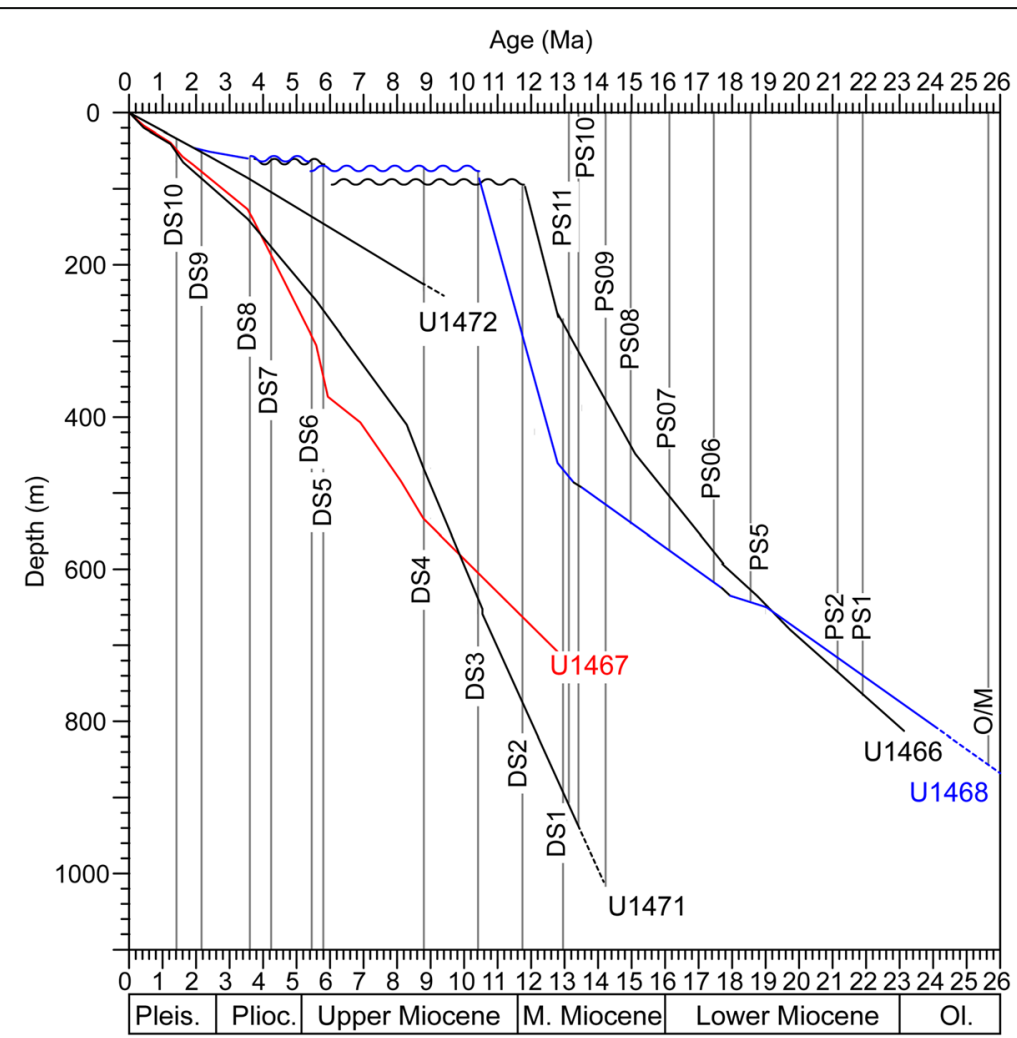

Fig. 7 Age-depth curves for the IODP Expedition 359 sites with age of sequence boundaries. Note that PS3 and PS5 are merged with the underlying boundaries so that individual ages cannot be discriminated for these horizons 
indicates that these deposits are Early Serravalian or older in age (Adams 1984).

\section{Timing of sequence boundaries}

Depths of the seismic sequence boundaries with lithology, age, mineralogy, and physical properties (gamma ray $\log$ ) are shown in Figs. 4 and 5, whereas their depths and ages are given in Table 2. The lowermost seismic reflection traced, i.e., the sequence boundary $\mathrm{O} / \mathrm{M}$, is the first turning point of the Maldives evolution with pelagic deposits overlying neritic limestones. Its age of $\sim 25.7 \mathrm{Ma}$ lies within the Upper Oligocene. For platform sequence boundary PS1, the second turning point of platform growth, the age assignment is 21.80-22 Ma. Sequence boundary PS2 appears to have an age of $\sim 21.3 \mathrm{Ma}$. Sequence boundary PS3 is amalgamated with PS2 at Sites U1466 and U1468 at seismic scale and, therefore, no age attribution is possible for this horizon. The same applies for PS5, which is the third turning point of platform growth, at 18.5-18.6 Ma.

Sequence boundaries PS6 to PS11 could be unequivocally determined at both Site U1466 and Site U1468 (Table 2). The fourth turning point in platform growth, which is defined at PS8 by a change from aggradation to progradation, has an age of $15.1 \mathrm{Ma}$. Sequence boundary DS1, which is the base of the drift succession, is dated as 12.9-13 Ma. The drift sequences were drilled at more than two sites (Figs. 3, 4, and 5, Table 2). Sequence boundary DS8, which marks the youngest turning point of the platform evolution, has an age range of about 2.85 to $4 \mathrm{Ma}$ when ages from all drilling sites are considered. However, the youngest age for DS8 results from Site U1465, a location where the seismic facies is indicative of a high energy hydrodynamic event. We therefore discard this age, which places DS8 into a time interval of 3.6-4.0 Ma.

\section{Discussion}

Reflooding of the archipelago and the deposition of sapropel-like sediments (late Oligocene-early Miocene)

Seismic horizon $\mathrm{O} / \mathrm{M}$ was interpreted as a drowning unconformity in previous work (Aubert and Droxler 1992, 1996), based on industrial seismic lines displaying a reflection which could be traced regionally. Wells ARI-1 (Inner Sea) and NMA-1 (North Malé Atoll) recorded a change from neritic to upper bathyal deposits above the level of this horizon (Aubert and Droxler 1996; Purdy and Betram 1993; Belopolsky and Droxler 2004a, 2004b). This regional deepening event compares well to the fining-upward trend registered in the succession recovered at Site U1468, where neritic limestones are overlain by wackestones and floatstones with large benthic foraminifers, and finally followed by mudstones and wackestones with planktonic foraminifers and calcareous nannoplankton (Fig. 4). This lithological succession, however, indicates a gradual deepening sequence, which culminated with the deposition of pelagic limestone. This is in contrast to the reported sedimentary evolution in well ARI-1, where the Paleogene-Neogene transition appears to correspond to an abrupt shift from shallow inner neritic conditions to deeper, outer neritic-upper bathyal conditions (Aubert and Droxler 1996). In any case, the new data from Site U1468, which is located $115 \mathrm{~km}$ north of well ARI-1 and $79 \mathrm{~km}$ northwest of well NMA-1, provide additional proof that large parts of the Maldives area underwent a substantial deepening during the time interval between 22 and $24 \mathrm{Ma}$.

The upward-deepening sequences that follow the first turning point of platform evolution corresponded with a widening of the Inner Sea area through backstepping of the shallow water parts of the platform towards the outer margins and edges of the ridge (Fig. 2, Purdy and Bertram 1993, Aubert and Droxler 1996). The corresponding platform interval below PS1 displays a lowrelief ramp-like profile of the sea floor dipping towards the Inner Sea (Fig. 2). Multiple sapropel-like intervals in the basinal part of these sequences indicate that the basin episodically had conditions which allowed deposition and preservation of an organic-rich sediments in the late Oligocene and early Miocene. A global sea-level rise of approximately $50 \mathrm{~m}$ following a late Oligocene sea-level lowstand is reported at the Oligocene-Miocene transition (Miller et al. 2011, Fig. 8). Such an amplitude of sea-level rise, however, seems insufficient to trigger an oxygen deficiency within the basin lacking steep margins, or to shut off the neritic carbonate factory at positions of all wells in the Maldives, including at NMA-1, and to induce pelagic sedimentation all over the known parts of the platform.

Upwelling and resultant high rates of organic matter production could theoretically be responsible for the formation of the sapropel-like layers. Today, the open Indian Ocean primary upwelling region is located in offequatorial regions at $5^{\circ}-10^{\circ} \mathrm{S}$ where the thermocline is shallow (Schott et al. 2009). IODP Sites U1466 and U1468 are located at $4^{\circ} 56^{\prime} \mathrm{N}$ but the Indian Plate crossed the equator at about $20 \mathrm{Ma}$ during its northward drift (van Hinsbergen et al. 2015). Because the tectonic plate configuration was different at the Oligocene-Miocene transition, the Indian Ocean circulation pattern for this time cannot be ascertained in detail. However, there is a possibility that the site locations during this time interval passed the zone of upwelling near the equator. Such high-nutrient input in the shallow-water realm would also reduce the growth potential of the neritic carbonate factories in particular reefs (Hallock and Schlager 1986). This would reconcile the occurrence of the sapropel deposits forming on a relatively open 


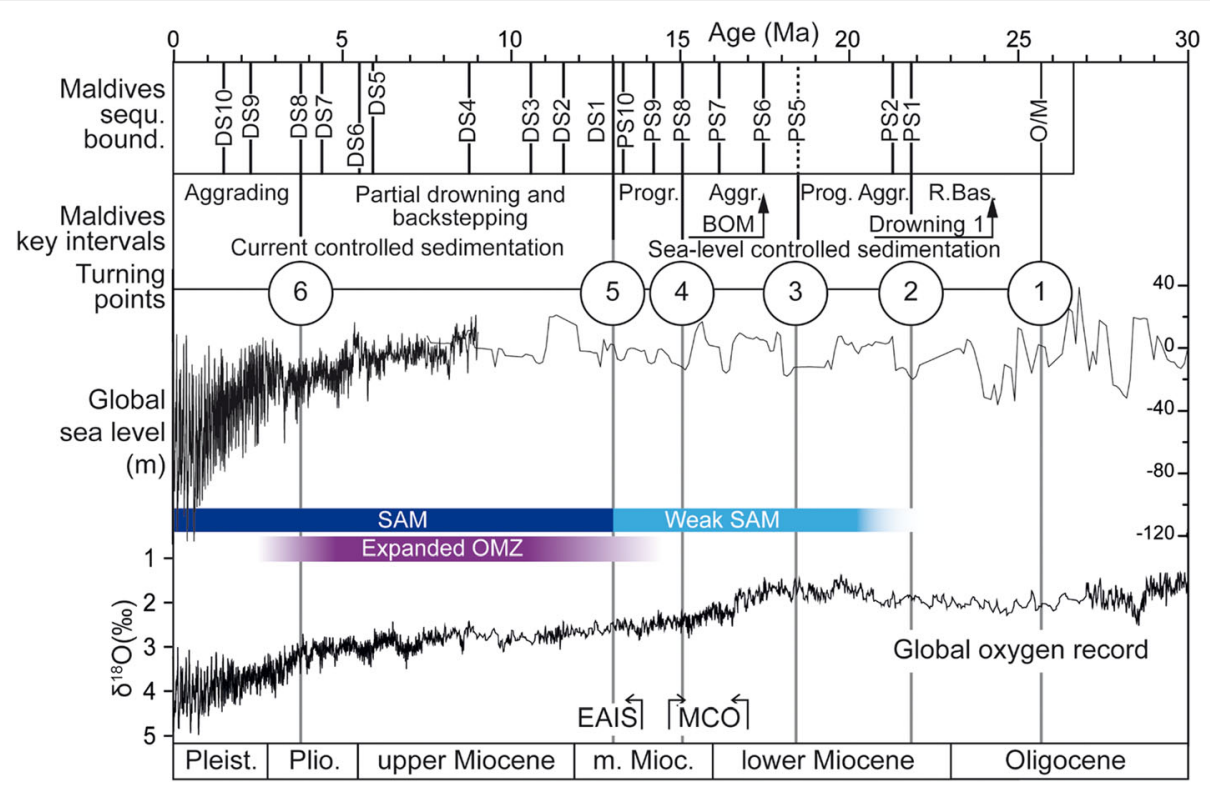

Fig. 8 Oligocene to Miocene evolution of the Maldives carbonate platform with ages of the sequence boundaries and key intervals representing changes of platform configuration. The global sea level curve is from Miller et al. (2005). The intensity of the South Asian Monsoon (SAM) and the expansion of the Oxygen Minimum Zone (OMZ) are after Betzler et al. (2016a). The global oxygen record is taken from Zachos et al. (2001). MCO Miocene Climate Optimum (after Holbourn et al. 2005, 2015), EAIS East Antarctic Ice Sheet expansion (after Holbourn et al. 2005), BOM Backstepping of the outer margin. Numbers in circles denominate turning points of the platform evolution; see text for discussion

carbonate bank. Alternatively, the sapropels could have formed during a period of stable water mass stratification in the Inner Sea basin. Additional research is needed to determine what mechanism ultimately triggered the formation of organic carbon rich deposits in the Inner Sea.

\section{Steepening of the ramp and sea-level controlled platform growth (early to middle Miocene)}

The second turning point of the platform evolution is the steepening of the carbonate ramp that started above sequence boundary PS1 at about $22 \mathrm{Ma}$ (Table 2, Figs. 2 and 8, Aubert and Droxler 1992, 1996). The continuous steeping resulted in a well-defined bank edge on top of sequence ps3 (Fig. 2). This geometrical turnover is also observed in several seismic lines located more than $150 \mathrm{~km}$ further south (Aubert and Droxler 1996). The evolution of ramp depositional system into an aggrading pattern established during the early Miocene indicates a rising sea level culminating in a highstand. This growth pattern is in concert with the global sea-level behavior in the early Miocene (Fig. 8). In particular, the aggrading growth pattern of this ramp system correlates well with the eustatic sea-level high determined in this time interval at around $20 \mathrm{Ma}$ (Fig. 8). The global sea-level lowering at around 19.5 Ma corresponds with the progradational geometry of sequence ps4 (Figs. 2 and 8).

Sequence boundary PS5, i.e., the third turning point of the platform evolution, correlates to a eustatic sea-level lowstand at about 18.5 Ma, but the overlying aggradational succession was deposited during at a time of a global sea-level highstand during the Miocene Climate Optimum (Fig. 8). This highstand is punctuated by two high-amplitude sea-level lowstands (Miller et al. 2005). Sequence boundaries PS6 and PS7 date these lowstands as 17 and $15.6 \mathrm{Ma}$, respectively. The fourth turning point in the platform growth evolution to an episode of progradation at $15.1 \mathrm{Ma}$ is in concert with an eustatic sea-level lowering at this time. Sequence boundaries PS9 and PS10 again formed at geological times of global sea level lowstands at 14.2 and $13.1 \mathrm{Ma}$, respectively.

The early and middle Miocene sequence boundaries, in addition to representing facies changes, correlate with elevated gamma ray values in the downhole logs. Such elevated values are related to elevated organic content in the sediment (Betzler et al. 2016a, 2017). The higher organic content of the sediment around sequence boundaries is likely the consequence of reduced sediment export from the platform. The organic content is probably diluted by elevated sediment export from the platform during highstands (Schlager et al. 1994).

The early to middle Miocene aggrading package formed mostly at the time of the MCO (Fig. 8), which lasted between 17 and $14.7 \mathrm{Ma}$ and was characterized by global annual mean temperatures $\sim 3-8{ }^{\circ} \mathrm{C}$ higher than preindustrial levels (Holbourn et al. 2015). Atmospheric $p \mathrm{CO}_{2}$ reconstructions indicate values reaching $\sim 500 \mathrm{ppm}$ (Foster et al. 2012, Zhang et al. 2013). The high-growth 
potential of the Maldives neritic carbonate platform coincides with a period of global warmth that had higher temperatures than today. This coral growth during such warm periods adds a new facet to the ongoing discussion about the reaction of neritic carbonate factories, in particular reefs, to global warming. The Maldives carbonate succession is the most appropriate location for further drilling to address the unanswered question about replacement of the neritic carbonate producers, i.e., the decline of corals and the dominance of red algae which has been related to global oceanographic changes (Bourrouilh-Le Jan and Hottinger 1988; Halfar and Mutti 2005).

The cooling of global climate, which began at $13.9 \mathrm{Ma}$ (Holbourn et al. 2005), seems to be out of phase by roughly 1.2 My from an eustatic sea-level lowering at 15.1 Ma (Miller et al. 2005, 2011; Fig. 8). The turning point 4 (PS8) of the Maldives carbonate edifice evolution correlates very well to this sea level lowering and trend of overall low sea level.

\section{The change to current-controlled sedimentation (middle Miocene -Pleistocene)}

The good correlation between eustatic changes and the stratigraphic packaging of the Maldives' sedimentary succession terminates at $13 \mathrm{Ma}$ (turning point 5) when currents start to control the sedimentation in the Inner Sea. The turning point of this platform evolution coincides with formation of DS1 at the base of the first drift sequence (Fig. 8). The base of the drift succession correlates with a partial drowning of the Maldives carbonate banks but does not correspond to a particular sea-level stand. It coincides with a minor sea-level highstand with a global sea-level position lying in the same range as the preceding sea-level highstands. A higher amplitude sealevel highstand occurs about 1 My after the partial drowning of the platform (Fig. 8). Only one of the drift sequence boundaries, DS3, appears to correlate with a particular sea-level lowstand. The onset of current influence coincides with initial platform drowning but the sequence of drowning steps ended with DS8, i.e., turning point 6 at $\sim 3.8 \mathrm{Ma}$, under conditions of a gradual eustatic lowering (Fig. 8; Betzler et al. (2009, 2013a); Lüdmann et al. (2013).

The reconstruction of this evolution of the Maldives system, whose ages are now well-constrained, provides strong evidence for the hypothesis of the monsoontriggered turnover of the Maldives evolution (Betzler et al. 2009). These authors proposed that the adverse effect of the monsoonal currents and topographically induced upwelling injected nutrients into surface waters of the carbonate banks. The current and upwelling processes are well-documented in the cores recovered during Expedition 359. The drift deposits were deposited under accelerated currents, and the expansion of the Indian
Ocean Oxygen Minimum Zone into the Maldives at $13 \mathrm{Ma}$ is indicated by increased Mn concentration in the sediment Betzler et al. 2016a. The timing of this evolution is in-line with other Indian Ocean records of the onset of the SAM. Gupta et al. (2015), based on stable isotope records at ODP sites in the Arabian Sea, proposed an onset of the modern monsoon system at 12.9 Ma, and the Bengal fan at Site U1451 at the same time registered an increase in sedimentation rate (France-Lanord et al. 2016).

\section{Carbonate platform controlled by sea level and currents}

It has been hypothesized that the Maldives carbonate platform edifice is subjected to two major controlling factors: sea-level changes and ocean currents (Betzler et al. 2013a). The relative impact of these factors on the stratigraphic stacking pattern of the carbonate platform are now elucidated by the correlation of the uppermost Oligocene to Miocene seismic facies to the cores and the downhole logs acquired at eight sites during IODP Expedition 359.

These data prove that a complete shift of the dominating controlling factor can occur in the evolution of a carbonate platform. A system, which is controlled by sea-level changes at a certain time, later can be controlled mainly by ocean currents. The Maldives example clearly depict that the possibility of such a scenario has to be considered, for example, when interpreting depositional geometries in seismic data sets.

Published data from elsewhere show that the Maldives is not a singular case with respect to an interaction of carbonate platform growth and ocean currents. Platforms in the Bahamas (Caribbean), the Marion Plateau (Australia), and the South China Sea show similar patterns of sudden increase of current control on the platform basin system (Anselmetti et al. 2000; Isern et al. 2004; Eberli et al. 2004, 2010). In the Bahamas and the Marion platforms, currents began shaping the carbonate platforms at 12.5 and 11.1, respectively. In the case of the South China Sea, monsoon wind-driven currents and topographically induced upwelling impinged on carbonate platforms beginning at $~ 13 \mathrm{Ma}$ (Shao et al. 2017).

It appears clear that the current imprint is a process restricted to icehouse episodes, when the world's oceans host a system of vigorous currents. It is expected that greenhouse carbonate platforms do not show such a current control. Last but not least, relevance of the new data from the Maldives is that drifts around carbonate platforms are not necessarily developing because currents are accelerated around an obstacle at the sea floor, i.e., the carbonate platform, but that the currents actively shape the platform and control stratigraphy.

The Maldives bear a record of two episodes of partial bank drowning. The first was at the Oligocene-Miocene 
transition. Following this episode, the platform fully recovered and later flourished and expanded. The second phase of partial drowning was definitive and only relict platforms survived. The first phase can be linked to a combination of high sea level and high paleoproductivity, but the second case is linked to the onset of a current system. The thick drift successions located on the downcurrent side of the drowned banks and the coarse grain size of some of the components in these sediments prove that these currents were vigorous. It is therefore proposed that, in this case, platform drowning was not only triggered by high nutrient injection into the shallow water, but also by the physical effects of ocean currents.

\section{Conclusions}

During the Neogene, Earth's climate has continuously reached thresholds that pushed the environment into new directions. While trends, such as the Miocene Climate Optimum and the subsequent overall cooling, are visible in the proxy record, threshold steps are ingrained in the sedimentary record. In carbonate platforms, such steps are sequence boundaries and stratigraphic packages with distinct sediment accumulation patterns. The Maldives sedimentary and seismic stratigraphic succession preserves a unique marine record, which conclusively demonstrates this context. Turning points in the platform growth patterns, such as the change from aggradation to progradation, are linked to overall trends of sea-level highstands and lowstands and sequence boundaries develop during short-termed sea-level lowstands. These straightforward relationships in the Maldives are, however, only valid for the lower and middle Miocene. Younger stratal packaging patterns and sequences are rather driven by the ocean circulation which triggers erosion and redistribution of sediments by currents. Current control on carbonate platform sedimentation and growth started nearly simultaneously in different platforms between 14 and $12 \mathrm{Ma}$, thus indicating that this mechanism is an important characteristic of icehouse worlds. This may also apply for other comparable climate conditions in Earth history.

\section{Acknowledgements}

This research used samples and data provided by the International Ocean Discovery Program (IODP). This study would not have been possible without the dedicated effort of the drilling crew, ship's crew, and scientific staff of the Drillship JOIDES Resolution. The Ministry of Fisheries and Agriculture of the Republic of the Maldives is thanked for granting the research permit. We would like to thank two anonymous reviewers and the handling editor Ryuji Tada for their constructive comments.

\section{Funding}

The expedition was funded by the US National Science Foundation (NSF); the European Consortium for Ocean Research Drilling (ECORD); the Ministry of Education, Culture, Sports, Science and Technology, Japan (MEXT); the Ministry of Science and Technology (People's Republic of China): the Korea Institute of Geoscience and Mineral Resources; the Australian Research
Council and the New Zealand Institute for Geological and Nuclear Sciences; and the Ministry of Earth Sciences (India). The German Federal Ministry of Education and Research is thanked for funding the seismic surveys (0350405, 03G0236A).

\section{Availability of data and materials}

All data are available at http://iodp.tamu.edu/database/

\section{Authors' contributions}

All authors were shipboard scientists of IODP Expedition 359. CB and GPE acted as co-chiefs and wrote the manuscript; DK and JDW were leading the stratigraphic effort; PKS and BNN performed geochemical and sedimentological analyses; CAZ coordinated the work and performed micropaleontological research; MAG, OMB, CLB, JAG, SH, SH, MI, LG, LL, JCL, ALHM, TL, MN, KN, LMP, SDP, JJGR, JR, ALS, CRS, XS, ZY, and JRY equally contributed to this work by sedimentological, micropaleontological, geochemical, magnestostratigraphic, physical property, and downhole logging analyses. All authors discussed the results and commented on the manuscript. All authors read and approved the final manuscript.

\section{Competing interests}

The authors declare that they have no competing interests.

\section{Publisher's Note}

Springer Nature remains neutral with regard to jurisdictional claims in published maps and institutional affiliations.

\section{Author details}

${ }^{1}$ Institute for Geology, CEN, University of Hamburg, Bundesstrasse 55, 20146 Hamburg, Germany. ${ }^{2}$ Department of Marine Geosciences, Department of Marine Geosciences, Rosenstiel School of Marine and Atmospheric Science, University of Miami, Miami, FL 33149, USA. ${ }^{3}$ Department of Geology and Geophysics, University of Edinburgh, Grant Institute, The King's Buildings, West Mains Road, Edinburgh EH9 3JW, UK. ${ }^{4}$ College of Petroleum Engineering and Geosciences, King Fahd University of Petroleum and Minerals, Dhahran 31261, Saudi Arabia. ${ }^{5}$ Department of Geological Sciences, Rutgers, The State University of New Jersey, 610 Taylor Road, Piscataway, NJ 08854-8066, USA. 'Department of Earth Sciences, University College London, Gower Street, London WC1E 6BT, UK. I International Ocean Discovery Program, Texas A\&M University, 1000 Discovery Drive, College Station, TX 77845, USA. ${ }^{8}$ Divisão de Geologia e Georecursos Marinhos, Instituto Portugues do Mar e da Atmosfera (IPMA), Avenida de Brasilia 6, 1449-006 Lisbon, Portugal. ${ }^{9}$ Centro de Ciencias do Mar (CCMAR), Universidade do Algarve, Faro, Portugal. ${ }^{10}$ Dr. Moses Strauss Department of Marine Geosciences, The Leon H. Charney School of Marine Sciences, University of Haifa, 31905 Carmel, Israel. ${ }^{11}$ Department of Geosciences, Princeton University, Guyot Hall, Princeton, NJ 08544, USA. ${ }^{12}$ Department of Geological Sciences, California State University Bakersfield, 9001 Stockdale Highway, Bakersfield, CA 93311, USA. ${ }^{13}$ Physical Properties Specialist, Ecole Nationale Superieure de Geologie, Universite de Lorraine, 2 rue du Doyen Marcel Roubault, 54501 Vandoeuvre-les-Nancy, France. ${ }^{14}$ Petroleum and Marine Research Division, Korea Institute of Geoscience and Mineral Resources (KIGAM), Gwahang-no 124, Yuseong-gu, Daejeon 305-350, Korea. ${ }^{15}$ Graduate School of Natural Science and Technology, Okayama University, 3-1-1 Tsushima-naka, Okayama 700-8530, Japan. ${ }^{16}$ Instituto Oceanográfico da Universidade de São Paulo, Praça do Oceanográfico, 191, São Paulo, SP 05508-120, Brazil. ${ }^{17}$ Istituto di Scienze della Terra, Università di Urbino, Via S. Chiara 27, 61029 Urbino, Italy. ${ }^{18}$ Department of Geology and Geophysics, Texas A\&M University, Mail Stop 3115, College Station, TX 77843-3115, USA.

${ }^{19}$ Department of Environmental Engineering for Symbiosis, Soka University, 1-236 Tangi-cyo, Hachioji-shi, Tokyo 192-0003, Japan. ${ }^{20} \mathrm{Geological}$ Oceanography Division, CSIR-National Institute of Oceanography, Dona Paula, Goa 403004, India. ${ }^{21}$ Graduate School of Science and Engineering, Yamagata University, 1-4-12 Kojirakawa-machi, Yamagata City 990-8560, Japan.

${ }^{22}$ Environmental Science and Policy Department, George Mason University, David King Hall Rm 3005, MSN 5F2, 4400 University Drive, Fairfax, VA 22030-4444, USA. ${ }^{23}$ Department of Geosciences, Geotechnology and Materials Engineering for Resources, Akita University, 1-1 Teagata-Gakuencho, Akita 010-8502, Japan. ${ }^{24}$ Lamont-Doherty Earth Observatory, Columbia University, Borehole Bldg. 61 Route 9W, Palisades, NY 10964, USA. ${ }^{25}$ Earth and Environmental Sciences, University of Technology Queensland, R-Block 317, 2 
George Street, Brisbane, QLD 4001, Australia. ${ }^{26}$ Key Laboratory of Marginal Sea Geology, South China Sea Institute of Oceanology, Chinese Academy of Sciences, 164 West Xingang Road, Guangzhou 510301, People's Republic of China. ${ }^{27}$ Department of Marine Geology, First Institute of Oceanography (FIO) State Oceanic Administration (SOA), \#6 Xian Xia Ling Road, Qingdao 266061, Shandong Province, People's Republic of China. ${ }^{28}$ Laboratory for Marine Geology, Qingdao National Laboratory for Marine Science and Technology, Qingdao, People's Republic of China.

Received: 1 September 2017 Accepted: 17 December 2017 Published online: 22 January 2018

\section{References}

Adams CG (1984) Neogene larger foraminifera, evolutionary and geological events in the context of datum planes In: Pacific Neogene Datum Planes: Contributions to Biostratigraphy and Chronology (Eds N. Ikebe, \& and R. Tsuchi). Univ. Tokyo Press, pp. 47-67.

Anselmetti FS, Eberli GP, Ding Z-D (2000) From the Great Bahama Bank into the Straits of Florida: a margin architecture controlled by sea-level fluctuations and ocean currents. Geol Soc Am Bull 112:829-844

Aubert O, Droxler AW (1992) General Cenozoic evolution of the Maldives carbonate system (equatorial Indian Ocean). Bull Centers Rech Explor Prod Elf-Aquitaine 16:113-136

Aubert O, Droxler AW (1996) Seismic stratigraphy and depositional signatures of the Maldive carbonate system (Indian Ocean). Mar Pet Geol 13:503-536

Backman J, Raffi I, Rio D, Fornaciari E, Pälike H (2012) Biozonation and biochronology of Miocene through Pleistocene calcareous nannofossils from low and middle latitudes. Newsl Stratigr 45(3):221-244

Bell DB, Jung SJA, Kroon D, Hodell DA, Lourens LJ, Raymo ME. (2015) Atlantic Deep-water Response to the Early Pliocene Shoaling of the Central American Seaway. Scientific Reports, 5, 12252.

Belopolsky, A.V., Droxler, A.W., 2004a. Seismic expressions and interpretations of carbonate sequences: the Maldives carbonate platform, equatorial Indian Ocean. Amer. Assoc. Petrol. Geol., Stud. Geol. 49

Belopolsky AV, Droxler AW (2004b) Seismic expressions of prograding carbonate bank margins: middle Miocene, Maldives, Indian Ocean. In: Eberli GP, Masaferro JL, Sarg JF (eds) Seismic imaging of carbonate reservoirs and systems, pp 267-290

Betzler C, Eberli GP, Alvarez Zarikian CA, Alonso-García M, Bialik OM, Blättler CL, Guo JA, Haffen S, Horozal S, Inoue M, Jovane L, Kroon D, Lanci L, Laya JC, Ling Hui Mee A, Lüdmann T, Nakakuni M, Nath BN, Niino K, Petruny LM, Pratiwi SD, Reijmer JJG, Reolid J, Slagle AL, Sloss CR, Su X, Swart PK, Wright JD, Yao Z, Young JR (2017) Expedition 359 summary. In: Betzler C, Eberli GP, Alvarez Zarikian CA, the Expedition 359 Scientists, Maldives Monsoon and Sea Level (eds) Proceedings of the International Ocean Discovery Program, vol 359. International Ocean Discovery Program, College Station https://doi. org/10.14379/iodp.proc.359.101.2017

Betzler C, Eberli GP, Kroon D, Wright JD, Swart PK, Nath BN, Alvarez-Zarikian CA, Alonso-García M, Bialik OM, Blättler CL, Guo JA, Haffen S, Horozal S, Inoue M, Jovane L, Lanci L, Laya JC, Mee ALH, Lüdmann T, Nakakuni M, Niino K, Petruny LM, Pratiwi SD, Reijmer JJG, Reolid J, Slagle AL, Sloss CR, Su X, Yao Z, Young JR (2016a) The abrupt onset of the modern South Asian Monsoon winds. Sci Rep 6:29838

Betzler C, Fürstenau J, Lüdmann T, Hübscher C, Lindhorst S, Paul A, Reijmer JJG, Droxler AW (2013a) Sea-level and ocean-current control on carbonateplatform growth, Maldives, Indian Ocean. Basin Res 25:172-196

Betzler C, Hübscher C, Lindhorst S, Lüdmann T, Reijmer JJG, Braga J-C (2016b) Lowstand wedges in carbonate platform slopes (Quaternary, Maldives, Indian Ocean). Depositional Rec 2:196-207

Betzler C, Hübscher C, Lindhorst S, Reijmer JJG, Römer M, Droxler AW, Fürstenau J, Lüdmann T (2009) Monsoonal-induced partial carbonate platform drowning (Maldives, Indian Ocean). Geology 37:867-870

Betzler C, Lüdmann T, Hübscher C, Fürstenau J (2013b) Current and sea-level signals in periplatform ooze (Neogene, Maldives, Indian Ocean). Sediment Geol 290:126-137

Bourrouilh-Le Jan FG, Hottinger LC (1988) Occurence of rhodolites in the tropical Pacific - a consequence of Mid-Miocene paleo-oceanographic change. Sediment Geol 60:355-367

Clift PD, Hodges KV, Heslop D, Hannigan, R, Van Long H, Calves G. (2008) Correlation of Himalayan exhumation rates and Asian monsoon intensity. Nature Geosc., 1, 875-880.
Cramer BS, Toggweiler JR, Wright JD, Katz ME, Miller KG. (2009) Ocean overturning since the Late Cretaceous: Inferences from a new benthic foraminiferal isotope compilation. Paleoceanography, 24, https://doi.org/10. 1029/2008PA001683.

De Vleeschouwer D, Vahlenkamp M, Crucifix M, Pälike H (2017) Alternating Southern and Northern Hemisphere climate response to astronomical forcing during the past 35 m.y. Geology 45:375-378

Duncan RA, Hargraves RB (1990) 40Ar/39Ar geochronology of basement rocks from the Mascarene Plateau, the Chagos Bank, and the Maldives Ridge. In: Duncan RA Backman J, Peterson LC et al (eds) Proceedings of the Ocean Drilling Program, Scientific Results, vol 115. Ocean Drilling Program, College Station, pp 43-51

Eberli GP, Anselmetti F, Betzler C, Bernoulli D, Van Konijnenburg J-H (2004) Calibration of seismic data from the western margin of Great Bahama Bank with exposed strata in the Maiella Mountains (Italy). AAPG Mem 81:207-250

Eberli GP, Anselmetti FS, Isern AR, Delius H (2010) Timing of changes in sea level and currents along Miocene platforms on the Marion Plateau. In: Morgan WA, George AD, Harris PM, Kupecz JA, Sarg JF (eds) Cenozoic carbonate systems of Australasia, pp 219-242

Flower BP, Kennett JP (1994) The middle Miocene climatic transition: East Antarctic ice sheet development, deep ocean circulation and global carbon cycling. Palaeogeogr Palaeoclimatol Palaeoecol 108:537-555. https://doi.org/ 10.1016/0031-0182 (94)90251-8

Foster GL, Lear CH, Rae JWB (2012) The evolution of pCO2, ice volume and climate during the middle Miocene. Earth Planet Sci Lett 341-344:243-254

France-Lanord C, Spiess V, Klaus A, Schwenk T, the Expedition 354 Scientists (2016) Proceedings of the International Ocean Discovery Program, Bengal Fan, vol 354. International Ocean Discovery Program, College Station https:// doi.org/10.14379/iodp.proc.354.2016

Fürstenau J, Lindhorst S, Betzler C, Hübscher C (2010) Submerged reef terraces of the Maldives (Indian Ocean). Geo-Mar Lett 30:511-515

Gupta AK, Yuvaraja A, Prakasam M, Clemens SC, Velu A (2015) Evolution of the South Asian monsoon wind system since the late Middle Miocene. Palaeogeogr Palaeoclimatol Palaeoecol 438:160-167

Halfar J, Mutti M (2005) Global dominance of coralline red-algal facies: a response to Miocene oceanographic events. Geology 33:481-484

Hallock P, Schlager W (1986) Nutrient excess and the demise of coral reefs and carbonate platform. PALAIOS 1:389-398

Holbourn A, Kuhnt W, Schulz M, Erlenkeuser H (2005) Impacts of orbital forcing and atmospheric carbon dioxide on Miocene ice-sheet expansion. Nature 438:483-487

Holbourn A, Kuhnt W, Kochhann KGD, Andersen N, Meier KJS (2015) Globa perturbation of the carbon cycle at the onset of the Miocene Climatic Optimum. Geology:123-126

Isern A, Anselmetti FS, Blum P (2004) A Neogene carbonate platform, slope and shelf edifice shaped by sea level and ocean currents, Marion Plateau (Northeast Australia). In: Eberli GP, Masaferro JL, Sarg JF (eds) Seismic imaging of carbonate reservoirs and systems, vol 81. AAPG Memoir, Tulsa, pp 291-307

Kroon D, Steens T, Troelstra SR (1991) Onset of monsoonal related upwelling in the western Arabian Sea as revealed by planktonic foraminifers. Proc. Ocean Drill. Proj., Sci. Results, 117, 257-263.

Lisiecki LE and Raymo ME. (2005) A Pliocene-Pleistocene stack of 57 globally distributed benthic D180 records. Paleoceanography, 20, https://doi.org/10 1029/2004PA001071.

Lüdmann T, Kalvelage C, Betzler C, Fürstenau J, Hübscher C (2013) The Maldives, a giant isolated carbonate platform dominated by bottom currents. Mar Pet Geol 43:326-340

Martini E (1971) Standard Tertiary and Quaternary calcareous nannoplankton zonation. In: Farinacci A (ed) Proceedings of the Second Planktonic Conference, Roma 1970, vol 2. Edizioni Tecnoscienza, Rome, pp 739-785

Miller KG, Kominz MA, Browning JV, Wright JD, Mountain GS, Katz ME, Sugarman PJ, Cramer BS, Christie-Blick N, Pekar SF (2005) The Phanerozoic record of global sea-level change. Science 310:1293-1298

Miller KG, Mountain GS, Wright JD, Browning JV (2011) A 180-million-year record of sea level and ice volume variations from continental margin and deep-sea isotopic records. Oceanography 24:40-53

Poore HR, Samworth R, White NJ, Jones SM, McCave IN (2006) Neogene overflow of Northern Component Water at the Greenland-Scotland Ridge. Geochemistry, Geophysics, Geosystems, 7, https://doi.org/10.1029/ 2005GC001085.

Purdy EG, Bertram GT (1993) Carbonate concepts from the Maldives, Indian Ocean, vol 34. AAPG, Stud. Geol, Tulsa, p 56 
Raffi I, Backman J, Fornaciari E, Pälike H, Rio D, Lourens L, Hilgen F (2006) A review of calcareous nannofossil astrobiochronology encompassing the past 25 million years. Quat Sci Rev 25:3113-3137

Rea DK. (1992) Delivery of Himalayan sediment to the northern Indian Ocean and its relation to global climate, sea level, uplift, and seawater strontium. In: Synthesis of Results from Scientific Drilling in the Indian Ocean. (Ed R.A. Duncan), Geophys. Monogr. Ser., Washington, DC, 70, 387-402.

Schlager W, Reijmer JJG, Droxler AW (1994) Highstand shedding of carbonate platforms. J Sediment Res B64:270-281

Schott FA, Xie S-P, McCreary JP (2009) Indian Ocean circulation and climate variability. Rev Geophys 47. https://doi.org/10.1029/2007RG000245.

Shao L, Li Q, Zhu W, Zhang D, Qiao P, Liu X, You L, Cui Y, Dong X (2017) Neogene carbonate platform development in the NW South China Sea: litho-, bio- and chemo-stratigraphic evidence. Mar Geol 385:233-243

Tomczak M, Godfrey JS (2003) Regional oceanography: an introduction. Daya Publishing House, Delhi, p 390

Van Hinsbergen DJJ, de Groot LV, van Schaik SJ, Spakman W, Bijl PK, Sluijs A, Langereis CG, Brinkhuis H (2015) A paleolatitude calculator for paleoclimate studies. PLoS One 10 https://doi.org/10.1371/journal.pone.0126946

Wright JD and Miller KG (1996) Control of North Atlantic Deep Water Circulation by the Greenland-Scotland Ridge. Paleoceanography, $11,157-170$.

Zachos J, Pagani M, Sloan L, Thomas E, Billups K (2001) Trends, rhythms, and aberrations in global climate $65 \mathrm{Ma}$ to present. Science 292:686-693

Zampetti V, Schlager W, van Konijnenburg J-H, Everts AJ (2004) Architecture and growth history of a Miocene carbonate platform from 3D seismic reflection data; Luconia Province, offshore Sarawak, Malaysia. Mar Pet Geol 21:517-534

Zhang YG, Pagani M, Liu Z, Bohaty SM, DeConto R (2013) A 40-million-year history of atmospheric CO2. Philos Trans R Soc Lond Ser A 371 dx.doi.org/ https://doi.org/10.1098/rsta.2013.0096

Zheng, H., Powell, C.M., Rea, D.K., Wang, J. and Wang, P. (2004) Late Miocene and mid-Pliocene enhancement of the East Asian monsoon as viewed from the land and sea. Glob. Planet. Change, 41:147-155.

\section{Submit your manuscript to a SpringerOpen ${ }^{\circ}$ journal and benefit from:}

- Convenient online submission

- Rigorous peer review

- Open access: articles freely available online

- High visibility within the field

Retaining the copyright to your article

Submit your next manuscript at $\boldsymbol{s p r i n g e r o p e n . c o m ~}$ 